Tropical Journal of Pharmaceutical Research July 2019; 18 (7): 1475-1480

ISSN: $1596-5996$ (print); 1596-9827 (electronic)

(C) Pharmacotherapy Group, Faculty of Pharmacy, University of Benin, Benin City, 300001 Nigeria.

\title{
Anti-nociceptive effect of gabapentin in mouse models of acute and chronic pain
}

\author{
Rajalakshimi Vasudevan*, Sadia Batool, Geetha Kandasamy, Saleh Farhan \\ Saeed, Nouf Saleh, Maha Mohammed, Arwa Gursan Awad \\ College of Pharmacy, King Khalid University, Abha, Kingdom of Saudi Arabia
}

*For correspondence: Email: aneesa@qau.edu.pk; Tel: +92-51-90643223

Sent for review: 9 January 2019

Revised accepted: 18 June 2019

\begin{abstract}
Purpose: To investigate the anti-nociceptive effect of gabapentin in acute and chronic pain models. Methods: Four mouse models of pain were used in this study. These comprised thermal tests (hot plate and tail immersion tests), and chemical tests (formalin and acetic acid-induced writhing tests). A total of seventy-two (72) albino mice weighing $25-40 \mathrm{~g}$ (mean weight $=32.5 \pm 5.1 \mathrm{~g}$ ) were used. In each test, the mice were randomly assigned to three sets of 6 mice each: control group, celecoxib group and drug treatment group. Each test was performed at intervals of 30, 60 and 90 min.

Results: During the acute phase, there was no significant decrease in foot raising (FR) or licking and biting $(L \& B)$ episodes among the groups $(p>0.05)$. However, these episodes were significantly $(p<$ $0.05)$ decreased in the second delayed phase, in the celecoxib and drug-treated groups, when compared with normal control group. Gabapentin significantly $(p<0.05)$ decreased pain response throughout the course of the thermal tests. The number of writhes within 30 min were significantly reduced in celecoxib and gabapentin-treated animals, compared with negative control group $(p<0.05)$. Gabapentin produced approximately $60 \%$ protection of writhing, similar to that produced by celecoxib, the standard non-steroidal anti-inflammatory drug (NSAID) used (61\%).

Conclusion: The results demonstrate that the gabapentin is effective against chronic inflammatory pain in mice and therefore can be potentially developed as an effective anti-inflammatory agent for humans.
\end{abstract}

Keywords: Gabapentin, Celecoxib, Pain, Antinociceptive effect, Formalin test

\begin{abstract}
This is an Open Access article that uses a fund-ing model which does not charge readers or their institutions for access and distributed under the terms of the Creative Commons Attribution License (http://creativecommons.org/licenses/by/4.0) and the Budapest Open Access Initiative (http://www.budapestopenaccessinitiative.org/read), which permit unrestricted use, distribution, and reproduction in any medium, provided the original work is properly credited.

Tropical Journal of Pharmaceutical Research is indexed by Science Citation Index (SciSearch), Scopus, International Pharmaceutical Abstract, Chemical Abstracts, Embase, Index Copernicus, EBSCO, African Index Medicus, JournalSeek, Journal Citation Reports/Science Edition, Directory of Open Access Journals (DOAJ), African Journal Online, Bioline International, Open-J-Gate and Pharmacy Abstracts
\end{abstract}

\section{INTRODUCTION}

Pain is an unpleasant sensation ranging from mild discomfort to agony caused by illness or injury, usually accompanied with actual tissue damage [1]. Pain arises from a number of pathologies such as nerve injury, disease states, trauma, or metabolic abnormalities [2]. Acute pain is considered to be momentary and as well easy to manage, whereas chronic pain persists beyond the duration of injury or disease [3]. Pain is a protective mechanism which occurs in response to exposure to injurious stimuli. It may damage both the central nervous system and peripheral nervous system [4]. Nociceptive receptors are responsive to stimuli that are physical or mechanical, thermal and chemical in nature [5]. 
Quality of life is greatly affected by acute or chronic pain. The different strategies employed for pain treatment are aimed at defense and reinvigoration. The two main groups of recognized remedies include opioids and NSAIDs [7]. These drugs are mere palliatives, since they are used for symptomatic treatment of pain $[1,8]$. Central analgesics are highly effective, but are less preferred, owing to their adverse effects, such as respiratory depression, and dependence. Peripheral analgesics cause gastrointestinal disturbances and renal lesions $[1,8]$. This has prompted alternative pharmacological management with drugs that produce lesser side effects.

In order to replace opioids and NSAIDs, drugs such as alpha receptor agonists, N-Methyl-DAspartate receptor (NMDA) antagonists, antidepressants and anticonvulsants have emerged as effective therapies for pain syndromes $[9,10]$.

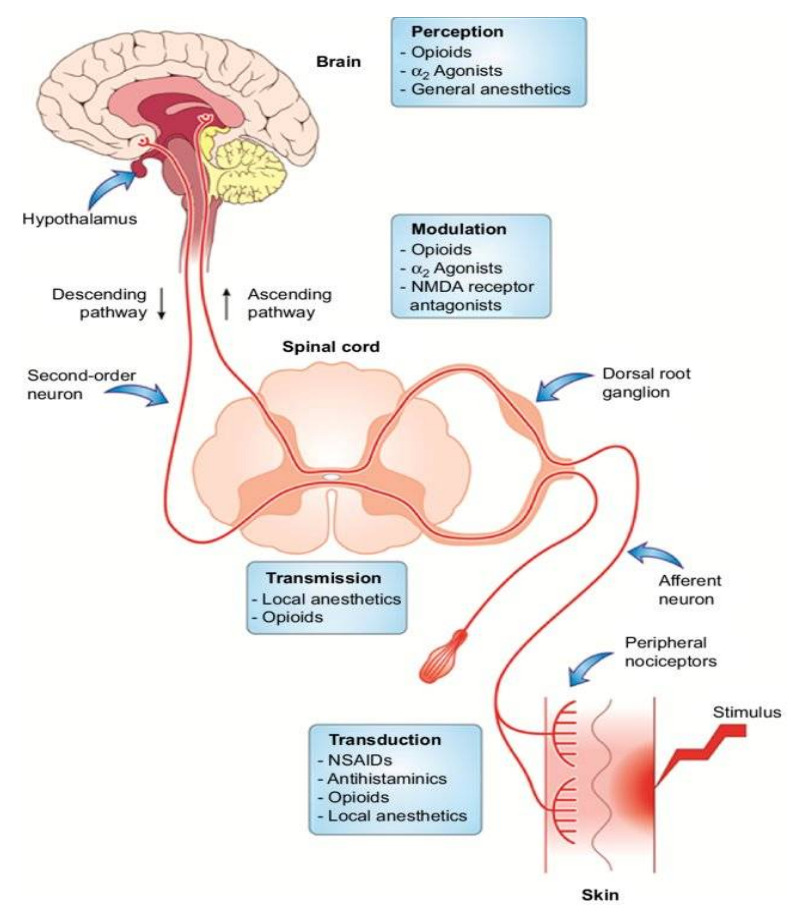

Figure 1: Physiology of pain and its management [13]

Gabapentin, a structural analogue of gammaaminobutyric acid (GABA) is an anticonvulsant and an analgesic [5]. Although it mechanism of action remains unclear, it is effective in treating neuropathic pain such as trigeminal neuralgia, peripheral neuropathy, chemotherapy and radiculopathy. Gabapentinoids act by blocking voltage-gated calcium channels, regulating neuronal excitability, inhibiting open of $\mathrm{K}^{+}$channels, inhibition of serotonergic neurotransmitter release, and release of inflammatory mediators $[11,12]$. The search for effective anticonvulsant drugs with antinociceptive activity is expected to lead to advancements in the management of pain. Therefore, the current study investigated the antinociceptive effect of gabapentin in acute and chronic pain models.

\section{EXPERIMENTAL}

\section{Materials}

Normal saline and formalin were obtained from College of Pharmacy, King Khalid University, Saudi Arabia. Gabapentin (Neuroplex ${ }^{\circledR} 300 \mathrm{mg}$ ) as well as celecoxib (Celcox ${ }^{\circledR} 200 \mathrm{mg}$ ) were gifts from Tabuk Pharmaceuticals (Saudi Arabia) and Lupin Pharmaceuticals (India), respectively.

\section{Experimental mice}

Albino mice $(\mathrm{n}=72$ ) weighing 25-40g (mean weight $=32.5 \pm 5.1 \mathrm{~g}$ ) were obtained from King Khalid University, Greigor, and used. They were placed in plastic cages under controlled environment at a temperature of $24 \pm 1^{\circ} \mathrm{C}$, with

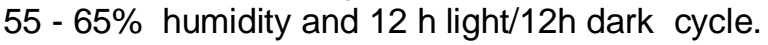
They were allowed access to standard mice feed and clean drinking water. The study protocol was designed in accordance with the Ethical Principles and Guidelines for Scientific Experiments on Animals (1995) [14]. The protocol was examined, and agreed by the Regional Ethics Committee, King Khalid University, Abha, Saudi Arabia (No. 2018 - 06 49).

\section{Drugs}

Gabapentin and celecoxib were prepared by dissolving them in sufficient volume of normal saline. Each was administered at a dose of 10 $\mathrm{ml} / \mathrm{kg}$ body weight (bwt).

\section{Mouse models of pain, and grouping}

Mouse models of pain used in this study were thermal test models such as tail immersion tests, hot plate tests, and chemical test models such as acetic acid-induced writhing and formalin tests. In each test, the mice were randomly categorized into three groups with 6 mice in each: normal (negative) control group, celecoxib (standard) control group and drug (test) treatment group. Normal control mice received normal saline (NS) $(10 \mathrm{ml} / \mathrm{kg}$, ip); mice in celecoxib group were treated with $20 \mathrm{mg} / \mathrm{kg}$ bwt of the drug i.p., while the treatment group rats received $32 \mathrm{mg}$ gabapentin $/ \mathrm{kg}$, ip). 


\section{Formalin test}

Typically formalin models used to assess acute and chronic pain. In this study, the formalin model is evaluated to assess the anti-nociceptive activity of gabapentin [15]. After $1 \mathrm{~h}$ of drug administration, $25 \mu \mathrm{L}$ of formol saline $(5 \mathrm{ml}$ formalin in $95 \mathrm{ml} \mathrm{NS}$ ) was subcutaneously given into the dorsal region of the hind paw of mice (right or left). Immediately after formol injection, the animals were placed individually in an observation tray and the drugs effect was evaluated by counting the number of paw licking, paw biting ( $L \& B)$ and durations of paw elevation $(F R)$ in the acute or neurogenic stages within 10 $\mathrm{min}$, and after $15-45 \mathrm{~min}$.

Group - I: Mice $(\mathrm{n}=6)$ treated with $50 \mu \mathrm{L}$ normal saline (i.p.) followed by an administration of 25 $\mu \mathrm{L}$ of $5 \%$ formalin (s.c.) $1 \mathrm{~h}$ later.

Group - II: Mice $(\mathrm{n}=6)$ treated with $50 \mu \mathrm{L}$ of 20 $\mathrm{mg} / \mathrm{kg}$ of celecoxib (i.p.) dissolved in normal saline [16] followed by an administration of $25 \mu \mathrm{L}$ of $5 \%$ formalin (s.c.) $1 \mathrm{~h}$ later.

Group - III: Mice $(n=6)$ treated with $50 \mu \mathrm{L}$ of 32 $\mathrm{mg} / \mathrm{kg}$ of gabapentin (i.p.) dissolved in normal saline [17] followed by an administration of $25 \mu \mathrm{L}$ of $5 \%$ formalin $1 \mathrm{~h}$ later.

\section{Tail immersion test}

It is performed as a model of acute pain based on Vogel procedures [18]. Tail immersion test with radiant heat is an adaptation of the method used on human subjects. After $1 \mathrm{~h}$ of drug administration, the tails of mice in the three groups were immersed in warm water. The reaction time for an animal to remove its tail from the warm water was recorded at intervals of 30 , 60 , and $90 \mathrm{~min}$.

\section{Hot plate test}

Feed was completely reserved $2 \mathrm{~h}$ prior to drug administration until the end of the experiment. After 30 min of drug administration, each animal was placed on a hot plate and responses such as jumping and licking of the hind paw were recorded at intervals of 30,60 and 90 min [19].

\section{Acetic acid-induced writhing reflex test (visceral nociception)}

Feed was completely inhibited $2 \mathrm{~h}$ prior to drug administration, and the three groups received the same treatment as in the formalin test $1 \mathrm{~h}$ before $0.85 \%$ acetic acid was given at a dose of 0.1 $\mathrm{ml} / \mathrm{kg}$, ip Writhing responses such as extension of the body and hind limbs were recorded within 30 min [20]. Reduction in the number of writhes was taken as the antinociceptive effect. Protection of abdominal writhing was calculated using Eq 1.

$\%$ Protection $(\%)=\{(A-B) /\} 100$

where $A=$ no. of writhing in the control group, and $B=$ no. of writhes in the drug treated mice [21].

\section{Statistical analysis}

The values are expressed as 'mean \pm SEM', and the statistical analysis was carried out using SPSS (V.21.0). Groups were compared using post-hoc Tukey test and the values of $p<0.05$ were considered statistically significant.

\section{RESULTS}

\section{Analgesic effect of gabapentin}

As shown in Table 1, during the acute phase, there were no significant decreases in foot raising (FR) or licking and biting (L\&B) episodes among the groups $(p>0.05)$. However, in comparison with control group these episodes were significantly $(p<0.05)$ decreased in the second delayed phase in the celecoxib and the drug treatment groups. During the second phase, FR decreased by $55.94 \%$ in the treatment group, and by $57.98 \%$ in celecoxib group. Inhibition of L\&B episodes by gabapentin was $55.63 \%$, while that of celecoxib was $58.73 \%$.

Table 1: Analgesic effect of gabapentin as determined using formalin test

\begin{tabular}{llcccc}
\hline \multirow{2}{*}{ Group } & \multirow{2}{*}{ Drugs \& dose } & \multicolumn{2}{c}{ FR (Mean \pm SEM) } & \multicolumn{2}{c}{ L\&B (Mean \pm SEM) } \\
\cline { 3 - 6 } & & Acute phase & $\begin{array}{c}\text { Delayed phase } \\
\text { (I) }\end{array}$ & Acute phase (I) & $\begin{array}{c}\text { Delayed phase } \\
\text { (II) }\end{array}$ \\
\hline I & 0.09\% n/saline (i.p.) & $14.83 \pm 0.31$ & $8.33 \pm 0.33$ & $24.33 \pm 1.15$ & $16.16 \pm 0.48$ \\
II & CXB, 20mg/kg (i.p.) & $13.16 \pm 0.31^{\text {NS }}$ & $3.5 \pm 0.22^{*}$ & $22.5 \pm 0.56^{\text {NS }}$ & $6.67 \pm 0.33^{*}$ \\
III & GBP, 32mg/kg (i.p.) & $13.67 \pm 0.33^{\text {NS }}$ & $3.67 \pm 0.21^{\circ}$ & $22.66 \pm 0.56^{\text {NS }}$ & $7.17 \pm 0.48^{\prime}$ \\
\hline
\end{tabular}

FR- Raising foot; L\&B - licking and biting. Each value is mean \pm SEM ( $n=6) ;{ }^{*} p<0.05$ in comparison with control; NS - non-significant; CXB - celecoxib; GBP - gabapentin; n/saline = normal saline 
Table 2: Analgesic effect of gabapentin as determined by tail immersion test

\begin{tabular}{llcccc}
\hline Group & Drug & \multicolumn{3}{c}{ Reaction time (sec) at a specific time (min) } \\
\cline { 2 - 6 } & & $\mathbf{0}$ min & $\mathbf{3 0}$ min & $\mathbf{6 0}$ min & $\mathbf{9 0 ~} \mathbf{m i n}$ \\
\hline I & $0.09 \% \mathrm{n} / \mathrm{saline} \mathrm{(i.p.)}$ & $2.66 \pm 0.21$ & $2.50 \pm 0.22$ & $2.83 \pm 0.16$ & $2.33 \pm 0.21$ \\
\hline II & $\mathrm{CXB}, 20 \mathrm{mg} / \mathrm{kg}$ (i.p.) & $3.00 \pm 0.26$ & $4.83 \pm 0.40$ & $5.83 \pm 0.31$ & $6.30 \pm 0.33$ \\
\hline III & GBP, $32 \mathrm{mg} / \mathrm{kg}$ (i.p.) & $3.16 \pm 0.31$ & $4.67 \pm 0.33$ & $6.00 \pm 0.36$ & $6.50 \pm 0.22$ \\
\hline
\end{tabular}

Each value is mean \pm SEM $(n=6) ;{ }^{*} p<0.05$ in comparison with control; NS - non-significant; CXB - celecoxib; GBP - gabapentin; $\mathrm{n} /$ saline = normal saline.

Table 3: Results of analgesic effect assessed using hot plate test

\begin{tabular}{|c|c|c|c|c|c|}
\hline \multirow[t]{2}{*}{ Group } & \multirow[t]{2}{*}{ Drug \& dose } & \multicolumn{4}{|c|}{ Reaction time (sec) at a specific time (min) } \\
\hline & & 0 min & $30 \mathrm{~min}$ & $60 \min$ & $90 \min$ \\
\hline I & $0.09 \% \mathrm{n} /$ saline (i.p.) & $7.00 \pm 0.36$ & $6.50 \pm 0.34$ & $6.33 \pm 0.42$ & $6.83 \pm 0.30$ \\
\hline II & CXB, $20 \mathrm{mg} / \mathrm{kg}$ (i.p.) & $6.33 \pm 0.21$ & $10.17 \pm 0.31$ & $12.00 \pm 0.36$ & $12.33 \pm 0.33$ \\
\hline III & GBP, 32 mg/kg (i.p.) & $6.66 \pm 0.33$ & $10.67 \pm 0.49$ & $11.67 \pm 0.42^{*}$ & $12.17 \pm 0.40$ \\
\hline
\end{tabular}

Each value is mean \pm SEM $(n=6) ;{ }^{*} p<0.05$ in comparison with control; NS - non-significant; CXB - celecoxib; $\mathrm{GBP}$ - gabapentin; $\mathrm{n} /$ saline $=$ normal saline

Table 4: Evaluation of analgesic effect of Gabapentin by writhing test

\begin{tabular}{llcc}
\hline Group & Drug & No: of writhes in $\mathbf{3 0 ~ m i n}$ & Protection (\%) \\
\hline I & $0.09 \% \mathrm{n} / \mathrm{saline}$ (i.p.) & $40.17 \pm 1.96$ & - \\
\hline II & CXB, $20 \mathrm{mg} / \mathrm{kg}$ (i.p.) & $15.83 \pm 1.35$ & 61 \\
\hline III & GBP, $32 \mathrm{mg} / \mathrm{kg}$ (i.p.) & $16.16 \pm 1.14$ & 60 \\
\hline
\end{tabular}

Each value is mean \pm SEM $(n=6) ;{ }^{*} p<0.05$; CXB - celecoxib; GBP - gabapentin; NS - normal saline

\section{Outcome of tail immersion test}

The time taken to withdraw its tail was significantly $(p<0.05)$ increased in celecoxib and the drug treatment groups as compared to the control group. Gabapentin significantly $(p<0.05)$ decreased pain response throughout the course of the test (Table 2).

\section{Outcome of hot plate test}

As shown in Table 3 , pain was significantly $(p<$ $0.05)$ lessened in celecoxib and drug treated groups at 30,60 , and 90 min in comparison with the control group.

\section{Effect of gabapentin on number of writhes in acetic acid induced writhing test}

As compared to the control group, the number of writhes within 30 min was significantly reduced in celecoxib and treatment groups $(p<0.05)$ and shown in table 4. Gabapentin demonstrated roughly $60 \%$ writhing protection, which was comparable to that of celecoxib, the standard NSAID used (61\%).

\section{DISCUSSION}

Pain is a distressing feeling often caused by intense or damaging stimuli. Acute pain infrequently becomes chronic pain since it mostly lasts for seconds. Chronic pain persevere for prolonged periods and also challenging to most medical treatments leading to severe problems [1].The present study investigated the antinociceptive effect of gabapentin in acute and chronic pain mouse models. Although the antinociceptive action of gabapentin remains unclear, the drug has been proved to be successful in treating many forms of neuropathic pain. The two main mechanisms anticipated for the antinociceptive effect of gabapentin includes the reduction of glutamatergic synaptic transmission and increase in the secretion of GABA [21-23].

In this study, the formalin test results showed that gabapentin exhibited a significant antinociceptive effect comparable to that of the standard drug celecoxib, during the delayed phase. Acute phase of formalin test involves excitation of peripheral nociceptors, while the delayed phase is usually thought to involve stimulation of central sensitization [24]. Previous studies have reported that in formalin test, gabapentin attenuated the delayed phase, and the underlying mechanism involved inhibition of the central component of pain via interaction with voltage-gated calcium channels [25]. Thermal stimuli tests are very useful in that they reflect changes at the spinal cord level, and centrallyacting antinociceptive agents exert their effects at this level. The thermal tests measure the intricate responses to non-inflammatory, acute nociceptive stimuli, and they are the preferred 
models for learning central analgesic activity. Analgesic drugs prolong the reaction time of the response provoked by immersing the tail end in warm water. It has been established that if a substance increases response time, such substance must be acting centrally through the opioid receptor [26]. It has been reported that recurring stimuli augment the reaction of an animal to a particular injurious stimulus [27]. Amplified opening of voltage-gated $\mathrm{Ca}^{2+}$ channels and increased release of afferent peptide results in the activation of prostanoid receptors [28]. It is likely that gabapentin exerts its action by blocking prostanoid receptors, or by inhibiting prostaglandin synthesis.

In this study, gabapentin significantly reduced abdominal constrictions with a percentage protection comparable to that of celecoxib. Acetic acid-provoked abdominal constriction is a responsive procedure for defining the outcome of analgesics peripherally. This chemical stimulant produces pain via activation of cyclooxygenase (COX) enzymes with resultant release of inflammatory molecules such as prostacyclin [29]. The present study results suggest that gabapentin may possess peripheral antinociceptive effect which is comparable to that of celecoxib, through a mechanism involving the inhibition of COX activity. It may also act by inhibiting peripheral nociceptors, or by potentiating the action of GABA.

\section{CONCLUSION}

The results of this study illustrate that gabapentin is effective against chronic inflammatory pain in mice and therefore shown some potentials for successful development as an effective antiinflammatory agent for humans.

\section{DECLARATIONS}

\section{Acknowledgement}

The authors wish to acknowledge with thanks the management of College of Pharmacy, King Khalid University, for rendering technical assistance during the course of this work.

\section{Conflict of interest}

No conflict of interest is associated with this work.

\section{Contributions of authors}

We declare that this work was done by all the authors named in the article and all liabilities pertaining to claims relating to the content of this article will be borne by the authors. The project work was designed by Rajalakshimi V. The experiment and manuscript writing was carried out by Rajalakshimi V, Sadia Batool, Geetha K, Saleh Farhan Saeed, Nouf Saleh, Maha Mohammed, Arwa Gursan Awad.

\section{Open Access}

This is an Open Access article that uses a funding model which does not charge readers or their institutions for access and distributed under the terms of the Creative Commons Attribution License (http://creativecommons.org/licenses/by/ 4.0) and the Budapest Open Access Initiative (http://www.budapestopenaccessinitiative.org/rea d), which permit unrestricted use, distribution, and reproduction in any medium, provided the original work is properly credited.

\section{REFERENCES}

1. Arguelles CF, Lopez JE, Soto VG. Peripheral antinociceptive action of morphine and the synergistic interaction with lamotrigine. Anesthesiology. 2002; 96 (4): $921-925$.

2. Collins SL, Moore RA, McQuay $H J$, Wi $\square$ en $P$. Antidepressants and anticonvulsants for diabetic neuropathy and post herpetic neuralgia: a quantitative systematic review. J. Pain Symptom Management. 2000; 20: 449-458.

3. Howard L, Fields MD. Pain free: Modern drugs and neuropathic pain. J. Korean Med. Sci. 2002; 22: 360367

4. Garland EL. Pain processing in the human nervous system: a selective review of nociceptive and biobehavioral pathways. Prim. Care. 2012; 39(3): 561571.

5. Grichnik K, Ferrante $F$. The difference between acute and chronic pain. Mt. Sinai J. Med. 1991; 58(3): 217-220.

6. Paulina S, Rafal F, Andrzej P, Mariola D. Assessment of pain: Types, mechanism and treatment. Annals of Agricultural Environmental Medicine. 2013; 1: 2-7.

7. Monks R. Psychotropic drugs. In: Wall. PD, Melzack. R. Textbook of Pain. Churchill Livingstone, Edinburgh, 1994; 963-989.

8. Dixit $R K$, Bhargava VK. Cholinergic mechanism in gabapentin analgesia. Indian Journal of Pharmacology. 2001; 33: 221- 222.

9. Campbell FG, Graham JG, Zilkha KJ. Clinical trial of carbamazepine in trigeminal neuralgia. J. Neurosurg. Neurol. Psychiatry. 1966; 29: 265- 267.

10. Maizels M, McCarberg B. Antidepressants and antiepileptic drugs for chronic non-cancer pain. Am. Fam. Physician. 2005; 71(3): 483- 490.

11. Chincholkar M. Analgesic mechanisms of gabapentinoids and effects in experimental pain models: a narrative 
review. British Journal of Anaesthesia. 2018; 120 (6): 1315-1334.

12. Bertrand S, Ng GY, Purisai MG, Wolfe SE, Severidt MW, Nouel D, Robitaille R, Low MJ, O'Neill GP, Metters $K$. The anticonvulsant, anti-hyperalgesic agent gabapentin is an agonist at brain gamma-aminobutyric acid type $B$ receptors negatively coupled to voltage-dependent calcium channels. Journal of Pharmacology and Experimental Therapeutics.2001; 298: 15-24.

13. Gur PD, Rajagopalan NI, Gautam D, Jaishid A, Prashant $N$. Evidence and consensus recommendations for the pharmacological management of pain in India. Journal of Pain Research.2017: 10:709-736.

14. Ethical principles and guidelines for experiments on animals. Swiss Academy of Medical Sciences. Experientia. 1995; 51(1):1-3.

15. Wheeler-Aceto $H$, Cowan A. Standardization of the rat paw formalin test for the evaluation of analgesics. Psychopharmacology. 1991; 104: 35-44.

16. Zhao $Y Q$, Wang $H Y$, Yin JB, Sun $Y$, Wang $Y$, Liang JC, Guo XJ, Tang K, Wang YT. The analgesic effects of celecoxib on the formalin-induced short- and long-term inflammatory pain. Pain Physician. 2017; 20: 575-584.

17. Waszkielewicz AM, Gunia A, Soczyska K, Marona $H$. Evaluation of anticonvulsants for possible use in neuropathic pain. Current Medicinal Chemistry. 2011; 18: 4344-4358.

18. Vogel HG, Vogel WH. Drug discovery and evaluation: Pharmacological assays. Berlin: Springer-Verlag. 1997.

19. Franzotti EM, Santos CVF, Rodrigues HMS, Mourao RHV, Andrade MR, Antoniolli AR. Anti-inflammatory, analgesic and acute toxicity of Sidacordiforlia L. J. Ethnopharmacol. 2000; 72(1-2): 273-277.

20. Koster $R$, Anderson $M$, Debeer EJ. Acetic acid for analgesic screening. Federation Proceedings. 1959; 18 : 412-415.
21. Goldlust A, Su TZ, Wity D, Taylor CP, Oxander D. Effects of anticonvulsant drug gabapentin on the enzymes in metabolic pathways of glutamate and GABA. Epilepsy Res. 1995; 22: 1-11.

22. Magnus L. Non epileptic uses of gabapentin. Epilepsia.1999; 40: 66-74.

23. Lu Y, Westlund KN. Gabapentin attenuates nociceptive behaviors in an acute arthritis model in rats. J. Pharmacol. Exp.Therp.1999; 290: 214-219.

24. Munro G. Pharmacological assessment of the rat formalin test utilizing the clinically used analgesic drugs gabapentin, lamotrigine, morphine, duloxetine, tramadol and ibuprofen: Influence of low and high formalin concentrations. European Journal of Pharmacology. 2009; 605 (1-3): 95-102.

25. Field MJ, Hughes J, Singh L. Further evidence for the role of the alpha (2) delta subunit of voltage dependent calcium channels in models of neuropathic pain. Br. J. Pharmacol. 2000; 131(2): 282-286.

26. Umamageswari A, Kudagi BL. Anti-inflammatory and analgesic properties of Ocimum sanctum: a comparative study using animal models. Int. J. Basic Clin. Pharmacol. 2015; 4(5): 981-986.

27. Godhwani S, Godhwani JL, Vyas DS. Ocimum sanctum: an experimental study evaluating its anti- inflammatory, analgesic and antipyretic activity in animals. J. Ethnopharmacol. 1987; 21(2): 153- 163.

28. Kumar V, Sinha $M$, Banerjee A, Mohanty J. Antinociceptive activity of methanolic extract of Ocimum gratissimum (labiate) on experimental animals. Int. J. Pharm. Pharm. Sci. 2011; 3(3): 64- 66.

29. Satyanarayana PS, Jain NK, Singh S, Kulkarni SK. Effect of selective inhibition of cyclooxygenase-2 on lipopolysaccharide-induced hyperalgesia. Inflammopharmacology. 2004; 12(1): 57-68. 